\title{
Ethnobotanical study of medicinal plants used by people in Zegie Peninsula, Northwestern Ethiopia Tilahun Teklehaymanot* and Mirutse Giday
}

\author{
Address: Endod and Other Medicinal Plants Unit, Aklilu Lemma Institute of Pathobiology, Addis Ababa University, P. O. Box 1176, Addis Ababa, \\ Ethiopia \\ Email: Tilahun Teklehaymanot* - tilahunmt@yahoo.com; Mirutse Giday - mirutseg@yahoo.com \\ * Corresponding author
}

Published: 14 March 2007

Journal of Ethnobiology and Ethnomedicine 2007, 3:12 doi:10.1186/1746-4269-3-12

This article is available from: http://www.ethnobiomed.com/content/3/I/12

(C) 2007 Teklehaymanot and Giday; licensee BioMed Central Ltd.

This is an Open Access article distributed under the terms of the Creative Commons Attribution License (http://creativecommons.org/licenses/by/2.0), which permits unrestricted use, distribution, and reproduction in any medium, provided the original work is properly cited.
Received: 2I December 2006

Accepted: 14 March 2007

\begin{abstract}
An ethnobotanical study was conducted from October 2005 to June 2006 to investigate the uses of medicinal plants by people in Zegie Peninsula, northwestern Ethiopia. Information was gathered from 200 people: 70 female and 130 males, using semistructured questionnaire. Of which, six were male local healers. The informants, except the healers, were selected randomly and no appointment was made prior to the visits. Informant consensus factor (ICF) for category of aliments and the fidelity level (FL) of the medicinal plants were determined. Sixty-seven medicinal plants used as a cure for 52 aliments were documented. They are distributed across 42 families and 64 genera. The most frequently utilized plant part was the underground part (root/rhizome/bulb) (42\%). The largest number of remedies was used to treat gastrointestinal disorder and parasites infections (22.8\%) followed by external injuries and parasites infections (22.1\%). The administration routes are oral (5l.4\%), external (38.6\%), nasal $(7.9 \%)$, and ear $(2.1 \%)$. The medicinal plants that were presumed to be effective in treating a certain category of disease, such as 'mich' and febrile diseases $(0.80)$ had higher ICF values. This probably indicates a high incidence of these types of diseases in the region, possibly due to the poor socio-economic and sanitary conditions of this people. The medicinal plants that are widely used by the local people or used as a remedy for a specific aliment have higher FL values (Carissa spinarum, Clausena anisata, Acokanthera schimperi, Calpurnia aurea, Ficus thonningii, and Cyphostemma junceum) than those that are less popular or used to treat more than one type of aliments (Plumbago zeylanicum, Dorstenia barnimiana).
\end{abstract}

\section{Background}

Ethnobotanical studies are often significant in revealing locally important plant species especially for the discovery of crude drugs. Right from its beginning, the documentation of traditional knowledge, especially on the medicinal uses of plants, has provided many important drugs of modern day $[1,2]$. Traditional medicine still remains the main resource for a large majority (80\%) of the people in Ethiopia for treating health problems and a traditional medical consultancy including the consumption of the medicinal plants has a much lower cost than modern medical attention [3-5].

Out of the total flowering plants reported from the world, more than 50,000 are used for medicinal purposes $[6,7]$. In Ethiopia, about 800 species of plants are used in the traditional health care system to treat nearly 300 mental and physical disorders. The wide spread use of traditional medicine among both urban and rural population in Ethiopia could be attributed to cultural acceptability, efficacy 
against certain type of diseases, physical accessibility and economic affordability as compared to modern medicine. Ethiopian traditional medical system is characterized by variation and is shaped by the ecological diversities of the country, socio-cultural background of the different ethnic groups as well as historical developments, which are related to migration, introduction of foreign culture and religion. Previous studies showed the existence of traditional medical pluralism in the country. In Ethiopia, either the knowledge from herbalists is passed secretively from one generation to the next through words of mouths or their descendants inherit the medico-spiritual manuscripts [8-12].

The study of Ethiopian medicinal plants has not been realized as fully as that of India or other traditional communities elsewhere [13]. In Ethiopia, though there has been some organized ethnomedicinal studies, there is limited development of therapeutic products and the indigenous knowledge on usage of medicinal plants as folk remedies are getting lost owing to migration from rural to urban areas, industrialization, rapid loss of natural habitats and changes in life style. In addition, there is a lack of ethnobotanical survey carried out in most parts of the country. In view of these, documentation of the traditional uses of medicinal plants is an urgent matter and important to preserve the knowledge. Furthermore, most of the ethnomedicinal studies in northern part of Ethiopia are focused on 'Medihanit Awakie' (professional traditional practitioners) and the ancient medico-magical and/or medico-spiritual manuscripts and old Gee'z manuscripts [11,14,15], and ignore the knowledge of ordinary people in the locality [16]. Thus, the purpose of this study is to investigate the traditional uses of medicinal plants by the ordinary people in Zegie Peninsula and to provide baseline data for future pharmacological and phytochemical studies.

\section{Methods}

\section{Description of the Study Area}

Zegie Peninsula $\left(11^{\circ} 43^{\prime} \mathrm{N}, 37^{\circ} 20^{\prime} \mathrm{E}\right)$ is located at 600 $\mathrm{km}$ northwest of Addis Ababa in the country's northwest highlands, at an altitude of approximately 1800 meters. It is partly surrounded by Lake Tana, which is the largest lake in Ethiopia and the source of the Blue Nile. Zegie Peninsula is about three hours motorboat drive or $37 \mathrm{~km}$ on land from Bahir Dar, the capital city of Amahra Regional State (Fig. 1). The residents are Amahra people and speak the country's official language Amharic. Tankwas (papyrus boats) of ancient design, manufactured on the shores of Lake Tana, are the alternative forms of transport for the local people between Zegie and Bahir Dar. There are seven monasteries on the peninsula from the 16 th and 17 th century. Ura Kidane Mhret, one of the monasteries, houses myriads of treasures, beautiful mural paintings, icons, scrolls and thousand-year-old manu- scriptsas well as crowns and dresses from Ethiopian Emperors. During the study time, there were no modern health facilities in the area. The main occupation of the people is fishing, and coffee plantation. Until recently, there was no farming practice because the monasteries in the peninsula had forbidden the use of any type of draft animal for farming. Nevertheless, currently, the people have started farming and clearing the forest for agricultural purposes and this may affect the natural habitats of some of the medicinal plants.

\section{Survey on the Use of Medicinal Plants}

The ethnobotanical surveys were carried out from October 2005 to June 2006 using semistructured questionnaire [17] and interview was conducted in Amharic. Prior to the administration of the questionnaire, conversations with the informants were held with the assistance of local Farmers' Association representative to elaborate the objective of the study and to build on trust with the common goal to document and preserve the knowledge on medicinal plants. Two hundred informants were interviewed out of about 2855 inhabitants (1,338 females and 1517 males) of the Zegie peninsula (unpublished data, Bahir Dar Zuria Woreda Administration), these included 130 males and 70 females. Of which, six were male local healers (the only ones found on the peninsula). The female informants' age ranges from 30 to 85 years and the mean age is 51 years, and the male informants' age ranges from 30 to 93 years and the mean age is 64 years. The informants, except the healers, were selected randomly and no appointment was made prior to the visits. They were asked to give their knowledge about the plants they use against a disease, plant parts harvested, method of preparation of the remedy, details of administration and the dosage. Specimens of the reported medicinal plants were collected during regular systematic walk in the fields and identified by specialists at the Aklilu Lemma Institute of Pathobiology and the National Herbarium of Addis Ababa University following the Flora of Ethiopia and Eritrea [18-21]. Voucher specimens were deposited at the Herbarium of Aklilu Lemma Institute of Pathobiology, Addis Ababa University.

\section{Data Analysis}

The reported aliments were grouped into 10 categories based on the information gathered from the interviewees. The categories were: evil eye and 'satan beshita' (devil sickness), external injuries and parasites infections, gastrointestinal disorder and parasites infections, 'mich' (febrile disease characterized by fever, headache, sweating, Herpes labialis, and muscle spasm) and febrile diseases, rabies and internal disease, respiratory and throat infections, sensorial disease, snake bite, swelling (non-infectious or infectious swelling) and cancer, and venereal disease and impotence. Informant consensus factor (ICF) was calcu- 


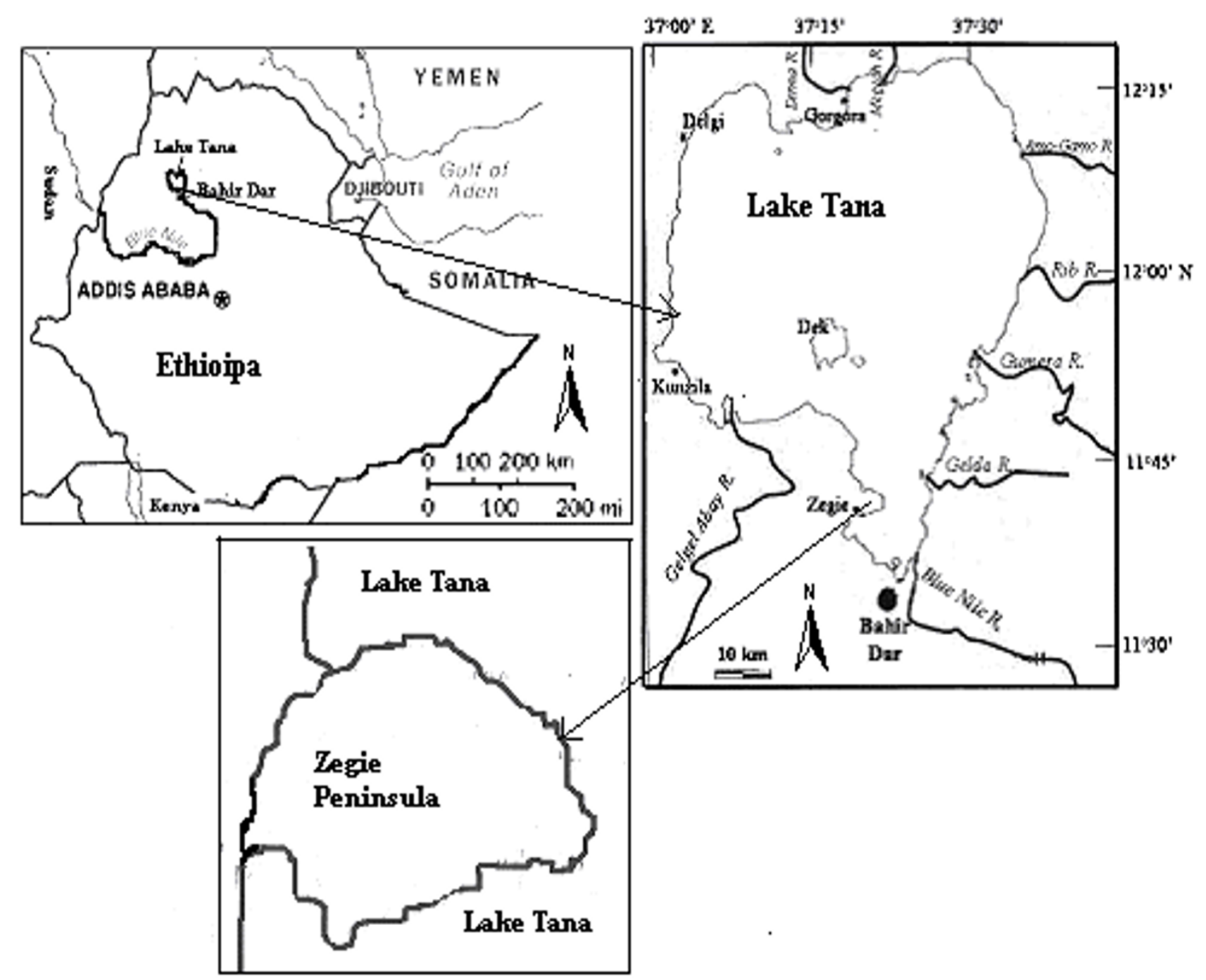

Figure I

Map of Zegie Peninsula in Ethiopia.

lated for each category of aliments to identify the agreements of the informants on the reported cures for the group of aliments. ICF was calculated as follows: number of use citations in each category $\left(n_{u r}\right)$ minus the number of species used $\left(n_{t}\right)$, divided by the number of use citations in each category minus one [22].

$$
\mathrm{ICF}=\frac{\mathrm{n}_{\mathrm{ur}}-\mathrm{n}_{\mathrm{t}}}{\mathrm{n}_{\mathrm{ur}}-1}
$$

The fidelity level (FL), the percentage of informants claiming the use of a certain plant for the same major purpose, was calculated for the most frequently reported diseases or ailments as:

$$
\mathrm{FL}(\%)=\frac{\mathrm{Np}}{\mathrm{N}} \times 100
$$

Where Np is the number of informants that claim a use of a plant species to treat a particular disease, and $\mathrm{N}$ is the number of informants that use the plants as a medicine to treat any given disease [23]. These two methods are helpful in the selection of plants for further studies.

\section{Result and discussion}

\section{Knowledge of Informants and Medicinal Plants}

Eighty two percent of informants reported remedies for 52 aliments. Of which $26 \%$ are females and $74 \%$ are males, 
which indicated that most people continue to use traditional systems of health care including medicinal plants alone or in combination with modern pharmaceuticals. This continued reliance of many African people on traditional medicines is partly due to economic circumstances, which place modern health facilities, services and pharmaceuticals out of the reach of the majority of the population. However, in many cases, it is also attributable to the widespread belief in the effectiveness of many traditional therapies. Even where western biomedical care is available, many people still prefer traditional treatments for treating many aliments $[4,5,11,24]$.

The females reported remedies to diseases associated to children such as 'mich', stomachache, 'kuruba' (diarrhea, dysentery, stomach disorder), dysentery, tonsillitis and babies' sickness (thinning, loss of appetite). The males reported (mean $=6.7 \pm 2.79$ ) more number of remedies than the females (mean $=2.3 \pm 0.9$ ) and there is a significant difference $(\mathrm{p}=0.004)$ between female and male and agrees with the previous reports of ethnobotanical studies in northern and southern Ethiopia [4,5]. This is because the traditional knowledge in the family or community is passed from male parent to his first-born son $[25,26]$.

All the healers were male and the number of aliments reported by them ranged from six to twenty. They also reported combination of multiple medicinal plants to treat an illness, whereas most of the non-healers, both females and males reported only a single medicinal plant treatment (Table 1, 2). The multiple prescriptions reported by the healers usually contain a range of pharmacologically active compounds; in some cases, it is not known which ingredients are important for the therapeutic effect and some are used as adjuvants [27].

The number of ethnomedicinally important plant species documented in Zegie Peninsula was 67. These species belong to 64 genera and 44 families. The genera Asteraceae, Euphorbiaceae, Fabaceae and Solanaceae were families with four species each followed by Malvaceae with three species and, Apocynaceae, Asclepiadaceae, Cucurbitaceae, Dracaenaceae, Moraceae, Rhamnaceae and Rutaceae, each contributing two species.

The most frequently utilized plant part was the underground part $($ root $/$ rhizome $/$ bulb $=42 \%)($ Table 4$)$. In studies conducted in Ethiopia, root (58.3\%) is one of the most extensively used plant part in preparation of traditional herbal medicine [11]. In this study, herbs are used predominantly (52\%, Fig. 2 ) as in most part of Ethiopia $(34.8 \%)[27,28]$.

The largest number of remedies was used to treat gastrointestinal disorder and parasites $(22.8 \%)$ followed by exter- nal injuries and parasites (22.1\%), rabies and internal diseases $(17.9 \%)$. The proportion of remedies used for treatment of gastrointestinal related disease are also high in most studies conducted in Ethiopia, accounting for $35 \%$ compared to other type of remedies that were compiled as being used against human aliments [28]. The rest were used to treat swelling and cancer $(8.3 \%)$, evil eye and devil sickness $(6.2 \%)$, sensorial disease $(6.2 \%)$, venereal disease and impotence (4.8\%), 'mich' and febrile diseases $(4.1 \%)$, respiratory and throat infection $(4.1 \%)$, and snake bite (3.4\%). Multiple plants treatments with different combinations of medicinal plants were used to treat seven external and internal illnesses. Seventy eight percent of the multiple plants treatments were roots and were prepared by mixing the ingredients with different proportions. Three were used to treat evil eye and one of the polyherbal remedy had nine medicinal plants (Table 3 ).

\section{Route and dosage of administration}

The administration routes are oral $(51.4 \%)$, external $(38.6 \%)$, nasal $(7.9 \%)$, and through the ear $(2.1 \%)$. The remedies are taken with water, skimmed milk, honey, tef injera (local thin bread made from tef, Eragrostis tef) and boiled coffee. The measurements used to determine the dosages are not standardized and depend on the age and physical appearance of the patient, sociocultural explanation of the illness, diagnosis and experience of individual herbalist $[5,11]$. Children are given less than adults, such as, one fourth of a coffee cup ( $2 \mathrm{ml}$ to $5 \mathrm{ml})$, whereas, an adult is given up to one glass (approximately $250 \mathrm{ml}$ ) depending on the type of illness and treatment. The quantity of plant part used is measured by number of leaves, seeds and fruits, and length of root. For example, seven young leaves of Justicia schimperiana are used to treat ascaris, seven seeds of Calpurnia aurea are used to treat diarrhea and about $2 \mathrm{~cm}$ of root of Dorstenia barnimiana is used to treat cancer. The frequency of treatment depends on the type of illness and severity. In preparation of polyherbal medicines, each medicinal plant is dried, powdered and stored separately, and the amount taken from each for any given disease varies.

\section{Veterinary Important Traditional Medicines}

Eight species of medicinal plants have veterinary importance. The plant parts used were leaf $(62.5 \%)$ and root $(37.5 \%)$. These are used as remedy for seven internal and external illnesses (Table 3 ). The number of veterinary important medicinal plants is low compared to those areas with culture of cattle raring. Giday and Ameni [29] documented 83 medicinal plants that are used to treat 37 types of livestock aliments. In our study area, people are not accustomed to cattle raring and, therefore, have low knowledge of veterinary important medicinal plants. 
Table I: Single medicinal plants treatment with parts used and preparation

\begin{tabular}{|c|c|c|c|c|}
\hline Species & Family & Local Name & Use(s) & Parts used and preparation \\
\hline \multirow[t]{2}{*}{ Achyranthes aspera L. } & Amaranthaceae & Telenzje & $\begin{array}{l}\text { 'shererit kusil' (Herpes } \\
\text { zoster) }\end{array}$ & Chewing fresh leaves \\
\hline & & & blood clotting & Dressing with crushed fresh leaves \\
\hline \multirow{2}{*}{$\begin{array}{l}\text { Acokanthera schimperi (A. } \\
\text { DC.) Schweinf. }\end{array}$} & Apocynaceae & Yemerz Enchet & 'kusil' & Dressing with crushed whole plant \\
\hline & & & $\begin{array}{l}\text { 'yetat merz' (bacterial } \\
\text { infection of nail) }\end{array}$ & Dressing with crushed fresh root \\
\hline \multirow[t]{2}{*}{ Allium sativum $L$. } & Alliaceae & Nech Shinkurt & 'ayne maz' (eye sickness) & Rubbing with warmed bulb \\
\hline & & & evil eye & Smelling aroma of bulb \\
\hline Asparagus africanus Lam. & Asparagaceae & Yeset Kest & 'sinfete wesib' & Root powder is eaten with chicken soup \\
\hline \multirow[t]{5}{*}{$\begin{array}{l}\text { Brucea antidysenterica J. F. } \\
\text { Mill. }\end{array}$} & Simaroubaceae & Aballo (Waginos) & $\begin{array}{l}\text { 'bullad' (weight loss fever, } \\
\text { itching, diarrhea) }\end{array}$ & $\begin{array}{l}\text { Fruit powder mixed with honey and } \\
\text { fermented for seven days is taken orally until } \\
\text { cure }\end{array}$ \\
\hline & & & $\begin{array}{l}\text { 'fintita sigelebet' } \\
\text { (Haemorrhoids) }\end{array}$ & $\begin{array}{l}\text { Fruit powder mixed with milk is taken orally } \\
\text { for three days }\end{array}$ \\
\hline & & & $\begin{array}{l}\text { 'mushuro' (weight loss, } \\
\text { dysentery and fever) }\end{array}$ & $\begin{array}{l}\text { Root powder mixed with honey is taken orally } \\
\text { until cure }\end{array}$ \\
\hline & & & dysentery & Juice of leaf is taken orally in the morning \\
\hline & & & 'chiffea' (Eczema) & $\begin{array}{l}\text { Dressing with inner bark paste mixed with } \\
\text { butter or oil }\end{array}$ \\
\hline Calpurnia aurea (Alt.) Benth. & Fabaceae & Digita & 'kuruba' & $\begin{array}{l}\text { Leaves or Fruit powder mixed with water or } \\
\text { honey is taken orally }\end{array}$ \\
\hline Carica papaya L. & Caricaceae & Papaya & malaria & Juice of leaves is taken orally \\
\hline Centella asiatica $\mathrm{L}$. & Apiaceae & Yeayit Joro & swelling & Dressing with leaf paste \\
\hline $\begin{array}{l}\text { Clausena anisata (Willd.) } \\
\text { Benth }\end{array}$ & Rutaceae & Limche & ear sickness & Juice of leaves is used as ear drop \\
\hline $\begin{array}{l}\text { Clausena anisata (Willd.) } \\
\text { Benth }\end{array}$ & Rutaceae & Limche & stomachache & Chewing root \\
\hline \multirow[t]{3}{*}{ Clematis hirsuta Perr \& Guill } & Ranunculaceae & Azo Hareg & 'mich' & Juice of fresh leaves is used as body lotion \\
\hline & & & cough & Juice of leaves with butter of fat is taken orally \\
\hline & & & swelling & Dressing with Leaf paste \\
\hline Commelina sp. & Commelinaceae & Yemariam Wuha & $\begin{array}{l}\text { allergic } \\
\text { ear infection }\end{array}$ & $\begin{array}{l}\text { Dressing with crushed fresh leaf } \\
\text { Juice of leaves as ear drop }\end{array}$ \\
\hline \multirow[t]{5}{*}{ Croton marcostachyus Del. } & Euphorbiaceae & Bissana & 'ekeke' (scabies) & $\begin{array}{l}\text { Dressing with Crushed leaves mixed with } \\
\text { butter or oil }\end{array}$ \\
\hline & & & 'kuruba' & $\begin{array}{l}\text { Leaves are eaten with wat(Diarrhoea, } \\
\text { dysentery, stomach disorder) (local soup) }\end{array}$ \\
\hline & & & $\begin{array}{l}\text { 'wef beshita' (hepatitis, } \\
\text { jaundice) }\end{array}$ & $\begin{array}{l}\text { Leaf powder mixed with water is taken orally } \\
\text { for seven days }\end{array}$ \\
\hline & & & diarrhea & Leaf powder mixed with water is taken orally \\
\hline & & & quaqucha (Tinea versicolor) & Rubbing and dressing with Latex from leaves \\
\hline \multirow[t]{6}{*}{ Cucumis ficifolius A. Rich. } & Curcurbitaceae & $\begin{array}{l}\text { Yemidir Embuay } \\
\text { (Este Melecot) }\end{array}$ & 'ayn bar tessa' & Chewing root \\
\hline & & & 'majrat getr' (meningitis) & Root powder mixed with honey taken orally \\
\hline & & & 'nessr' (epistaxis) & Juice of root applied though nose \\
\hline & & & 'wef beshita' & $\begin{array}{l}\text { Root powder is taken mixed with skimmed } \\
\text { milk or noug orally in the morning }\end{array}$ \\
\hline & & & rabies & Root powder is eaten with tef kita \\
\hline & & & $\begin{array}{l}\text { stomachache, 'kuruba', } \\
\text { umbilical cord labouring }\end{array}$ & Chewing root \\
\hline $\begin{array}{l}\text { Cussonia holstii Harms ex. } \\
\text { Engl. }\end{array}$ & Araliaceae & Sila & burning & Dressing with crushed fresh leaves \\
\hline $\begin{array}{l}\text { Cyphostemma junceum } \\
\text { (Webb) Decoings ex Wild \& } \\
\text { Drummond }\end{array}$ & Vitaceae & Etse Zewe & snake bite & Chewing roots \\
\hline \multirow[t]{4}{*}{ Datura stramonium } & Solanaceae & Astenagir & swelling & Dressing with leaf paste \\
\hline & & & tooth ache & $\begin{array}{l}\text { Fresh leaves are boiled with water and the } \\
\text { vapour is inhaled }\end{array}$ \\
\hline & & & 'fore fore' (dandruff) & Fresh leaves are used for rubbing and dressing \\
\hline & & & 'kusil' & Dressing with leaf paste \\
\hline $\begin{array}{l}\text { Dorstenia barnimiana } \\
\text { Schwienf. }\end{array}$ & Moraceae & Work Bemeda & 'wef beshita' & $\begin{array}{l}\text { Root powder is taken with skimmed milk or } \\
\text { noug orally in the morning }\end{array}$ \\
\hline
\end{tabular}


Table I: Single medicinal plants treatment with parts used and preparation (Continued)

\begin{tabular}{|c|c|c|c|c|}
\hline & & & $\begin{array}{l}\text { 'yeahya kintarot' (donkey's } \\
\text { wart) }\end{array}$ & Dressing with root paste \\
\hline & & & cancer & Making small opening and inserting the root \\
\hline & & & rabies & $\begin{array}{l}\text { Root powder is taken with skimmed milk or } \\
\text { noug orally in the morning for seven days }\end{array}$ \\
\hline & & & syphilis & $\begin{array}{l}\text { Root powder is taken with honey orally in the } \\
\text { morning }\end{array}$ \\
\hline & & & $\begin{array}{l}\text { weight loss, diarrhea and } \\
\text { fever }\end{array}$ & $\begin{array}{l}\text { Root powder mixed honey and fermented for } \\
\text { seven days is taken orally in the morning until } \\
\text { cured }\end{array}$ \\
\hline Draceana steudeneri Engl. & Dracaenaceae & Etse Patos & evil eye & Root is burned and smoke is inhaled \\
\hline Echinops kebericho Mesfin & Compositae & Kebercho & evil eye & $\begin{array}{l}\text { Root powder is sprinkled on burning charcoal } \\
\text { and smoke is inhaled }\end{array}$ \\
\hline Euphorbia abyssinica J. F. & Euphorbiaceae & Qulqwal & venereal diseases & Latex is eaten with tef of wheat kit \\
\hline & & & $\begin{array}{l}\text { 'wef beshita' } \\
\text { rabies }\end{array}$ & $\begin{array}{l}\text { Latex mixed with water is taken orally } \\
\text { Root powder mixed water is taken orally }\end{array}$ \\
\hline Euphorbia tirucalli L. & Euphorbiaceae & Kinchib & 'kintarot' & Rubbing with latex and dressing \\
\hline & & & 'kusil' & Dressing with latex \\
\hline Ferrula communis $\mathrm{L}$. & Apiaceae & Dog & cough & $\begin{array}{l}\text { Filtrate of boiled root mixed with honey taken } \\
\text { orally until cured }\end{array}$ \\
\hline Ficus thonningii Blume. & Moraceae & Chibha & $\begin{array}{l}\text { 'ayn bar tessa' (lose of } \\
\text { appetite) }\end{array}$ & Root with Noug is eaten \\
\hline & & & diarrhea & Chewing root \\
\hline & & & stomachache & Chewing inner Bark \\
\hline Glinus lotoides L. & Molluginaceae & Meterea & tapeworm & Fruit powder mixed with noug is taken orally \\
\hline Gnidia glauca (Fresen) & Thymelaeaceae & Beto & rabies & $\begin{array}{l}\text { Root powder mixed with skimmed milk is } \\
\text { taken orally for seven days }\end{array}$ \\
\hline Gossypium herbaceum L. & Malvaceae & Tit & snake bite & Chewing root \\
\hline $\begin{array}{l}\text { Hagenia abyssinica (Bruce) J. } \\
\text { F. Gmel. }\end{array}$ & Rosaceae & Kosso & 'kosso' (tape worm) & $\begin{array}{l}\text { Powder mixed with water and fermented over } \\
\text { night is taken orally in the morning }\end{array}$ \\
\hline $\begin{array}{l}\text { Helinu mystacinus (Ait.) E. } \\
\text { Mey. ex Steud }\end{array}$ & Rhamnaceae & Esat Abered & burning & Dressing with crushed fresh leaves \\
\hline Huernia concinna N. E. Br. & Asclepiadaceae & Yelam Tute & 'kusil', swelling & Dressing with crushed fresh leaf \\
\hline Impomea sp. & Convolvulaceae & Filatsut & $\begin{array}{l}\text { babies' sickness } \\
\text { cancer }\end{array}$ & $\begin{array}{l}\text { Bathing with crushed leaf and stem } \\
\text { Making small opening and inserting the root }\end{array}$ \\
\hline Indigofera spicata Forssk. & Fabaceae & Yebab Alenga & $\begin{array}{l}\text { babies' sickness } \\
\text { stomachache }\end{array}$ & $\begin{array}{l}\text { Bathing with crushed fresh leaf and stem } \\
\text { Chewing root }\end{array}$ \\
\hline $\begin{array}{l}\text { Justicia schimperiana (Hochst. } \\
\text { ex A. Nees) T. Anders }\end{array}$ & Acanthaceae & Sensel (Smiza) & 'wef beshita', 'kuruba' & Juice of leaves is taken orally \\
\hline & & & evil eye & Smelling the aroma of fresh root \\
\hline Kalanchoe petitana A. Rich. & Crassulaceae & Endehuahula & swelling & Making small opening and inserting the root \\
\hline Millettia ferruginea (Hochst.) & Fabaceae & Birbira & 'mujelea' (chigger) & Dressing with fruit paste mixed with butter \\
\hline & & & $\begin{array}{l}\text { 'tfre metmte' (bacterial } \\
\text { infection of nails) }\end{array}$ & Dressing with leaf paste \\
\hline & & & 'yejoro kunkun' (earache) & Juice of leaves or stem is used as ear drop \\
\hline & & & amoeba & $\begin{array}{l}\text { Fruits powder mixed with honey is taken } \\
\text { orally }\end{array}$ \\
\hline $\begin{array}{l}\text { Mimusops kummel Bruce ex. } \\
\text { DC. }\end{array}$ & Sapotaceae & Eshe & amoeba & Eating fruits \\
\hline Momordica foetida Schumach & Cucurbitaceae & Qura Hareg & 'zuresh' (babies sickness) & Bathing with crushed fresh root \\
\hline Myrtus communis L. & Myrtaceae & Ades & $\begin{array}{l}\text { 'fore fore' (Dandruff) } \\
\text { diarrhea, stomach disorder }\end{array}$ & $\begin{array}{l}\text { Bathing with crushed fresh leaves } \\
\text { Juice of leaf is taken orally in the morning }\end{array}$ \\
\hline Ocimum lamiifolium Hochst. & Lamiaceae & Dama Kesse & 'kusil' & Fresh crushed leaves dressing \\
\hline Ocimum lamiifolium Hochst. & Lamiaceae & Dama Kesse & $\begin{array}{l}\text { 'kusil' } \\
\text { 'mich' }\end{array}$ & $\begin{array}{l}\text { Dressing with Bark paste } \\
\text { Juice of leaves is taken with coffee orally }\end{array}$ \\
\hline Pergularia daemia L. & Asclepiadaceae & Yeayit Hareg & snake bite & Making small cut at location and inserting root \\
\hline Phytolacca dodecandra L'Herit & Phytolaceae & Endod (Male) & 'kuruba' & $\begin{array}{l}\text { Root or leaf powder mixed with water is } \\
\text { taken orally }\end{array}$ \\
\hline & & & 'kusil' & Dressing with Fruit paste \\
\hline & & & $\begin{array}{l}\text { 'wef beshita' } \\
\text { rabies }\end{array}$ & $\begin{array}{l}\text { Leaf powder mixed with water is taken orally } \\
\text { Root paste is taken with tef kita in the } \\
\text { morning for seven days }\end{array}$ \\
\hline
\end{tabular}


Table I: Single medicinal plants treatment with parts used and preparation (Continued)

\begin{tabular}{|c|c|c|c|c|}
\hline \multirow[t]{5}{*}{ Plumbago zeylanicum L. } & Plumbaginaceae & Amira & 'kurtimat' (rheumatic Pain) & $\begin{array}{l}\text { Fresh leaves are boiled and the filtrate is taken } \\
\text { with honey orally for seven days }\end{array}$ \\
\hline & & & cancer & $\begin{array}{l}\text { Root powder mixed with digne (sulphur) is } \\
\text { applied }\end{array}$ \\
\hline & & & cough & $\begin{array}{l}\text { Fresh leaves are boiled and the filtrate is taken } \\
\text { with fermented butter orally }\end{array}$ \\
\hline & & & snake bite & Chewing Leaves \\
\hline & & & swelling & Dressing with root paste \\
\hline Podocarpus gracilis & Podocarpaceae & Zigba & vomiting & Juice of leaves is taken orally \\
\hline Rhamnus prinoides $\mathrm{L}$. & Rhamnaceae & Gesho & 'chiffea' (Eczema) & $\begin{array}{l}\text { Appling leaf paste mixed with butter as } \\
\text { ointment }\end{array}$ \\
\hline Ricinus communis $\mathrm{L}$. & Euphorbiaceae & Kachima & $\begin{array}{l}\text { 'kuruba' } \\
\text { tooth ache }\end{array}$ & $\begin{array}{l}\text { Juice of root is taken orally } \\
\text { Chewing fresh root }\end{array}$ \\
\hline \multirow[t]{2}{*}{ Rumex nepalensis Spreng. } & Polygonaceae & Tult & $\begin{array}{l}\text { 'entil siwerd' (tonsillitis), } \\
\text { 'kuruba' }\end{array}$ & Juice of root is taken orally \\
\hline & & & umbilical cord labouring & Tying fresh root around west \\
\hline Ruta chalepensis L. & Rutaceae & Tena Adam & $\begin{array}{l}\text { evil eye } \\
\text { flue }\end{array}$ & $\begin{array}{l}\text { Smelling aroma of fresh leaf and stem } \\
\text { Juice of leaves is taken with coffee }\end{array}$ \\
\hline Sansevieria erythraeae Mattei & Dracaenaceae & Algeti/cheret & 'sinfete wesib' (impotence) & Root powder is taken with tef potage \\
\hline Sida ternata $\mathrm{L}$. F. & Malvaceae & Yemidir Hareg & 'lashet' (fungal disease) & Dressing with crushed fresh leaves \\
\hline Solanum marginatum L.f & Solanaceae & Geber Embuay & 'kusil', swelling & Dressing with crushed fresh root \\
\hline \multirow[t]{5}{*}{$\begin{array}{l}\text { Stephania abyssinica (Dillon. } \\
\text { \& A. Rich.) Walp. }\end{array}$} & Menispermaceae & $\begin{array}{l}\text { Kib Kitel } \\
\text { (Etse Eyesus) }\end{array}$ & 'kuruba' & Juice of root is taken orally \\
\hline & & & babies' sickness & $\begin{array}{l}\text { Juice of leaves mixed with butter is taken } \\
\text { orally }\end{array}$ \\
\hline & & & stomachache & Juice of leaf and stem is taken orally \\
\hline & & & 'kintarot' & Dressing with stem paste \\
\hline & & & 'girfita' (fever, headache) & Bathing with crushed fresh leaves \\
\hline Stereospermum kunthianum & Bignoniaceae & Zana & $\begin{array}{l}\text { 'kola kusil' (infected cut or } \\
\text { wound) }\end{array}$ & Dressing with Bark paste \\
\hline Taverniera abyssinica A. Rich & Fabaceae & Dingetegna & Vomiting, dysentery & Chewing root \\
\hline Verbascum sinaiticum Benth. & Scrophulariaceae & Daba Keded & $\begin{array}{l}\text { 'kusil' } \\
\text { diarrhea, stomachache }\end{array}$ & $\begin{array}{l}\text { Dressing with Fresh crushed leaves } \\
\text { Juice of root is taken orally }\end{array}$ \\
\hline \multirow[t]{7}{*}{ Verbena officinalis L. } & Verbenaceae & Atuch & 'gusmit' (stomach disorder) & Juice of leaves is taken orally \\
\hline & & & $\begin{array}{l}\text { 'yeshererit beshita' (Herpes } \\
\text { zoster) }\end{array}$ & Dressing with leaf paste \\
\hline & & & ear sickness & Juice of fruit with olive oil is used as ear drop \\
\hline & & & evil eye & Smelling of aroma of fresh root \\
\hline & & & snake bite & Chewing root \\
\hline & & & stomachache & Chewing root \\
\hline & & & 'wesfat' (ascaris) & Juice of root is taken orally \\
\hline $\begin{array}{l}\text { Vernonia adoensis Sch. Bip. ex } \\
\text { Walp. }\end{array}$ & Asteraceae & Este Mossa & menstrual disorders & Root are chewed with honey \\
\hline \multirow[t]{4}{*}{ Vernonia amygdalina Del. } & Asteraceae & Girawa & 'entil siwerd' (Tonsillitis) & Juice of leaf is taken orally \\
\hline & & & $\begin{array}{l}\text { 'likift' (devil sickness, } \\
\text { madness) }\end{array}$ & Root is burned and smoke is inhaled \\
\hline & & & $\begin{array}{l}\text { 'satan beshita' (devil } \\
\text { sickness) }\end{array}$ & Bathing with crushed fresh leaves \\
\hline & & & $\begin{array}{l}\text { evil eye, 'satan beshita', } \\
\text { 'tesbo beshita' (epidemic } \\
\text { disease) }\end{array}$ & $\begin{array}{l}\text { Root powder is sprinkled on burning charcoal } \\
\text { and smoke is inhaled }\end{array}$ \\
\hline \multirow[t]{2}{*}{ Ximenia americana L. } & Olacaceae & Enkoye & 'entil siwerd' (tonsillitis) & Juice of bark is taken orally \\
\hline & & & 'kusil' & Dressing with bark paste \\
\hline \multirow[t]{2}{*}{ Zehneria scabra } & Asteraceae & $\begin{array}{l}\text { Hareg Ressa } \\
\text { (Este Sabek, } \\
\text { Shahirit) }\end{array}$ & 'mich' & $\begin{array}{l}\text { Leaves and stem are boiled and the vapour is } \\
\text { inhaled and bathing }\end{array}$ \\
\hline & & & 'kintarot' (wart) & Pressing with warmed stem \\
\hline Zingiber officinale Rosc. & Zingiberaceae & Zinjible & stomachache & Chewing rhizome \\
\hline
\end{tabular}


Table 2: Multiple medicinal plants treatment with parts used and preparation

\begin{tabular}{|c|c|c|c|c|c|}
\hline \multicolumn{2}{|c|}{ Species } & \multirow{2}{*}{$\begin{array}{l}\text { Family } \\
\text { Malvaceae }\end{array}$} & \multirow{2}{*}{$\begin{array}{l}\text { Local name } \\
\text { Ablalit }\end{array}$} & \multirow{2}{*}{$\begin{array}{l}\text { Use(s) } \\
\text { 'sinfete wesib' } \\
\text { (impotence) }\end{array}$} & \multirow{2}{*}{$\begin{array}{l}\text { Parts used and preparation } \\
\text { Root powder taken with tella } \\
\text { (local beverage) orally }\end{array}$} \\
\hline I & Pavonia urens Cav. & & & & \\
\hline 2 & Asparagus africanus Lam. & Asparagaceae & Set Kest & & \\
\hline 3 & Ferrula communis $\mathrm{L}$. & Apiacae & Dog (Ramiron) & & \\
\hline 4 & Clerodendrum myricoides (Hochst.) Vatke & Verbenaceae & Misrich & & \\
\hline I & Carissa spinarum L. & Apocynaceae & Agam & evil eye & $\begin{array}{l}\text { Sprinkling root powder on } \\
\text { burning charcoal and inhaling } \\
\text { smoke }\end{array}$ \\
\hline 2 & Capparis tomentosa Lam. & Capparidaceae & Gumero & & \\
\hline 3 & Verbascum sinaiticum Benth. & Scrophulariaceae & Daba Keded & & \\
\hline 4 & Achyranthes aspera $\mathrm{L}$. & Amaranthaceae & Telenzje & & \\
\hline 5 & $\begin{array}{l}\text { Justicia schimperiana (Hochst. ex A. } \\
\text { Nees) T. Anders }\end{array}$ & Acanthaceae & Sensel (Smiza) & & \\
\hline I & Carissa spinarum L. & Apocynaceae & Agam & evil eye & $\begin{array}{l}\text { Sprinkling root powder on } \\
\text { burning charcoal and smoke } \\
\text { inhaled }\end{array}$ \\
\hline 2 & Capparis tomentosa Lam. & Capparidaceae & Gumero & & \\
\hline 3 & Asparagus africanus Lam. & Asparagaceae & Set Kest & & \\
\hline 4 & Clausena anisata (Willd.) Benth & Rutaceae & Limchi & & \\
\hline 5 & Draceana steudeneri Engl. & Dracaenaceae & Etse Patos & & \\
\hline 6 & $\begin{array}{l}\text { Justicia schimperiana (Hochst. ex A. } \\
\text { Nees) T. Anders }\end{array}$ & Acanthaceae & Senel & & \\
\hline 7 & Echinops kebericho Mesfin & Asteraceae & Kebercho & & \\
\hline 8 & Ruta chalepensis L. & Rutaceae & Tena Adam & & \\
\hline 9 & Allium sativum $\mathrm{L}$. & Alliaceae & Nech Shnkurt & & \\
\hline I & Carissa spinarum L. & Apocynaceae & Agam & evil eye & $\begin{array}{l}\text { Root paste with water taken } \\
\text { orally }\end{array}$ \\
\hline 2 & Capparis tomentosa Lam. & Capparidaceae & Gumero & & \\
\hline 3 & Clausena anisata (Willd.) Benth & Rutaceae & Limchi & & \\
\hline 1 & Croton marcostachyus Del. & Euphorbiaceae & Bissana & $\begin{array}{l}\text { stomachache } \\
\text { disorder }\end{array}$ & $\begin{array}{l}\text { Leaves, root and seeds boiled in } \\
\text { butter taken orally }\end{array}$ \\
\hline 2 & Solanum indicum L. & Solanaceae & Nech Embuay & & \\
\hline 3 & Eragrostis tef (Zucc.) Trotter & Poaceae & Tef & & \\
\hline I & Brucea antidysenterica J. F. Mill. & Simaroubaceae & Aballo (Waginos) & 'chiffea' & Dressing root paste with honey \\
\hline 2 & Cucumis ficifolius A. Rich. & Cucurbitaceous & Yemidir Embuay & & \\
\hline 1 & Brucea antidysenterica J. F. Mill. & Simaroubaceae & Aballo & craziness & $\begin{array}{l}\text { Bathing with crushed fresh leaves } \\
\text { and root }\end{array}$ \\
\hline 2 & Podocarpus gracilis & Podocarpaceae & Zigba & & \\
\hline
\end{tabular}

Table 3: Medicinal plants of veterinary importance with parts used and preparation

\begin{tabular}{|c|c|c|c|c|c|}
\hline Species & Family & Local name & Habit & Use(s) & Preparation \\
\hline Achyranthes aspera L. & Amaranthaceae & Telenzje & Herb & blood clotting & Dressing with crushed leaves \\
\hline Calpurnia aurea (Alt.) Benth. & Fabaceae & Digita & Tree & dysentery & Leaf paste mixed with water is applied orally \\
\hline Croton marcostachyus Del. & Euphorbiaceae & Bissana & Tree & 'wef beshita' & $\begin{array}{l}\text { Making small opening and inserting crushed } \\
\text { leaves with salt and soot in the opening }\end{array}$ \\
\hline $\begin{array}{l}\text { Cyphostemma junceum (Webb) } \\
\text { Decoings ex Wild \& Drummond }\end{array}$ & Vitaceae & Etse Zewe & Climber & snake bite & Crushed fresh root is applied orally \\
\hline Ficus thonningii Blume. & Moraceae & Chibha & Tree & stomach disorder & Crushed fresh root is applied orally \\
\hline Ocimum lamiifolium Hochst. & Lamiaceae & Dama Kesse & Shrub & 'mich' & $\begin{array}{l}\text { Juice of leaves with Dagusa injera is applied } \\
\text { orally }\end{array}$ \\
\hline Phytolacca dodecandra L'Herit & Phytolaceae & Endod (Male) & Shrub & 'wef beshita' & Crushed fresh leaves is applied orally \\
\hline Plumbago zeylanicum L. & Plumbaginaceae & Amira & Herb & swelling & Dressing with root paste \\
\hline
\end{tabular}




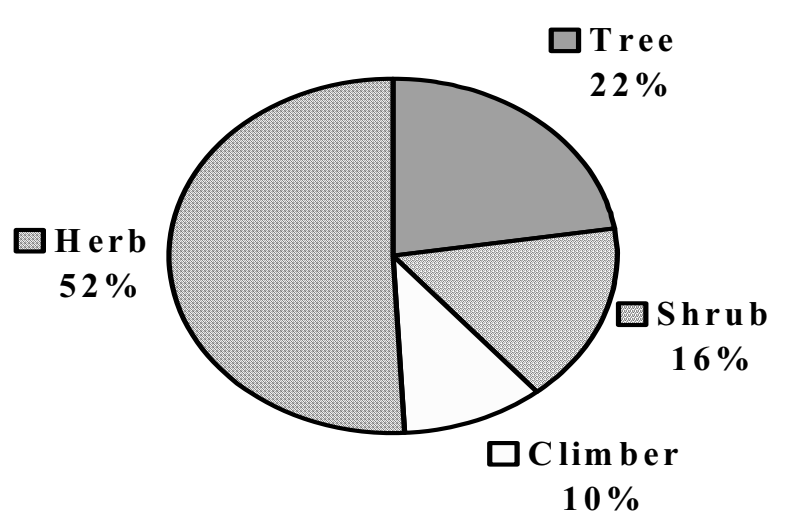

Table 4: Frequency of plant parts used for the preparation of remedies

\begin{tabular}{lcc}
\hline Plant parts used & Number of medicinal plant species & Percentage \\
\hline Leaf & 53 & $37 \%$ \\
Root & 58 & $40 \%$ \\
Flower & 10 & $7 \%$ \\
Leaf/Stem & 4 & $3 \%$ \\
Leaf/Root & 3 & $2 \%$ \\
Bark & 6 & $4 \%$ \\
Latex & 4 & $3 \%$ \\
Rhizome & 1 & $1 \%$ \\
Bulb & 2 & $1 \%$ \\
Seed & 1 & $1 \%$ \\
Stem & 2 & $1 \%$ \\
Whole & 1 & $1 \%$ \\
\end{tabular}

Figure 2

Percentages of habits of medicinal plants.

Table 5: ICF values of category of aliments

\begin{tabular}{|c|c|c|c|c|c|}
\hline Category & Species & (\%) All Species & Use citations & (\%) All use citations & ICF value \\
\hline 'Mich' and febrile diseases & 6 & $9 \%$ & 26 & $11 \%$ & 0.80 \\
\hline Evil eye and satan beshita & 13 & $20 \%$ & 41 & $18 \%$ & 0.70 \\
\hline Respiratory and throat infections & 6 & $9 \%$ & 15 & $7 \%$ & 0.64 \\
\hline Rabies and internal disease & 17 & $26 \%$ & 45 & $20 \%$ & 0.64 \\
\hline Gastrointestinal disorder and parasites infections & 23 & $35 \%$ & 60 & $26 \%$ & 0.63 \\
\hline Venereal disease and impotence & 7 & $11 \%$ & 13 & $6 \%$ & 0.50 \\
\hline External injuries and parasites infections & 19 & $29 \%$ & 33 & $14 \%$ & 0.44 \\
\hline Snake bite & 4 & $6 \%$ & 6 & $3 \%$ & 0.40 \\
\hline Swelling and cancer & 9 & $14 \%$ & 14 & $6 \%$ & 0.38 \\
\hline Sensorial disease & 4 & $6 \%$ & 5 & $2 \%$ & 0.25 \\
\hline
\end{tabular}

\section{Informants consensus and Species Use Value}

The medicinal plants that are presumed to be effective in treating a certain disease have higher ICF values. Table 5 shows disease categories with relatively higher ICF values: 'mich' and febrile diseases (0.80), evil eye and satan beshita (devil sickness) (0.70), and respiratory and throat infections (0.64). This may indicate high incidence of these types of diseases in the region, possibly due to the poor socio-economic and sanitary conditions of the people. The categories of diseases that are only treated by the healers and those that are rare have lower ICF values. These include swelling and cancer (38), and sensorial disease (0.25). The medicinal plants that are widely used by the local people have higher FL values than those that are less popular. On the other hand, medicinal plants that are known as remedies of a single aliment have $100 \%$ fidelity level than those that are used as remedies for more than one type of aliment. For example, Plumbago zeylanicum is used to treat cancer, respiratory infection, swelling, and rheumatic pain and its FL value is $40 \%$ (Table 6).

\section{Declaration of competing interests}

The author(s) declare that they have no competing interests.

\section{Authors' contributions}

The authors have made substantive intellectual contributions to this study in data collection, identification of plants, preparation of the manuscript and proof reading.

\section{Acknowledgements}

We are very much grateful to all the local informants and healers who shared their knowledge on the use of medicinal plants with us. Without their contribution, this study would have been impossible. We would also like to thank the Associate Vice President Office for Research and Publication, Addis Ababa University for the grant to conduct this study. 
Table 6: FL value of medicinal plants

\begin{tabular}{|c|c|c|c|}
\hline Species and Family & Local name & Therapeutical uses & Fidelity level (FL) \\
\hline Carissa spinarum L. Apocynaceae & Agam & evil eye & $100 \%$ \\
\hline Clausena anisata (Willd.) Benth Rutaceae & Limbche & evil eye & $100 \%$ \\
\hline $\begin{array}{l}\text { Acokanthera schimperi (A. DC.) Schweinf. } \\
\text { Apocynaceae }\end{array}$ & Yemerz Enchet & 'kusil, yetat merz' & $100 \%$ \\
\hline Calpurnia aurea (Alt.) Benth. Fabaceae & Digita & diarrhea & $100 \%$ \\
\hline Ficus thonningii Blume. Moraceae & Chibha & 'ayn bar teza' & $100 \%$ \\
\hline $\begin{array}{l}\text { Cyphostemma junceum (Webb) Decoings ex } \\
\text { Wild \& Drummond Vitaceae }\end{array}$ & Etse Zewe & snake bite & $100 \%$ \\
\hline Sansevieria erythraeae Mattei Dracaenaceae & Algeti/chiret & 'sinfete wesib' & $100 \%$ \\
\hline Zehneria scabra Asteraceae & Hareg Ressa (Este Sabek) & 'mich', 'kintarot' & $86 \%$ \\
\hline $\begin{array}{l}\text { Stephania abyssinica (Dillon. \& A. Rich.) Walp. } \\
\text { Menispermaceae }\end{array}$ & Kib Kitel/Etse Eyesus & stomachache/'kuruba', babies' sickness & $80 \%$ \\
\hline Phytolacca dodecandra L'Herit Phytolaceae & Endod & 'wef beshita', 'kusil' & $75 \%$ \\
\hline Verbena officinalis L. Verbenaceae & Atuch & stomachache, evil eye, snake bite & $73 \%$ \\
\hline Ocimum lamiifolium Hochst. Lamiaceae & Dama Kesse & 'mich', 'kusil' & $67 \%$ \\
\hline Croton marcostachyus Del. Euphorbiaceae & Bissana & gastrointestinal disorder, 'wef beshita' & $63 \%$ \\
\hline $\begin{array}{l}\text { Justicia schimperiana (Hochst. ex A. Nees) T. } \\
\text { Anders Acanthaceae }\end{array}$ & Sensel (Smiza) & evil eye, 'wef beshita', 'kuruba' & $63 \%$ \\
\hline Capparis tomentosa Lam. Capparidaceae & Gumero & evil eye, 'satan beshita, 'tesbo beshita' & $57 \%$ \\
\hline Cucumis ficifolius A. Rich. Curcurbitaceae & Yemidir Embuay & $\begin{array}{l}\text { stomachache, 'kuruba', 'chiffea', 'majrat getr', } \\
\text { 'nessr', rabies, 'wef beshita' }\end{array}$ & $50 \%$ \\
\hline Plumbago zeylanicum L. Plumbaginaceae & Amira & coughing, 'kurtimat', cancer, swelling & $40 \%$ \\
\hline Dorstenia barnimiana Schweinf. Moraceae & Work Bemeda & $\begin{array}{l}\text { cancer, rabies, syphilis, 'wef beshita', 'yeahya } \\
\text { kintarot', 'mushuro' }\end{array}$ & $22 \%$ \\
\hline
\end{tabular}

\section{References}

I. Cox AP, Balick JM: Ethnobotanical Research and traditional Health Care in Developing Countries, plants, people and culture W.H. Freeman and Co; 1996.

2. Flaster T: Ethnobotanical approaches to the discovery of bioactive compounds. Progress in new crops. In Proceedings of the third national symposiu ASHS Press, Alexandria; 1996:56I-565.

3. Abebe D, Hagos E: Plants as a primary source of drugs in the traditional health practices of Ethiopia. In Plant Genetic resources of Ethiopia Edited by: Engles JMM, Hawkes JG, Worede M. Cambridge University Press, Cambridge; 1991:101-II3.

4. Asfaw D, Abebe D, Urga K: Traditional medicine in Ethiopia: perspectives and developmental efforts. I Ethiop Med Pract 1999, I(2): I |4- I7.

5. Addis G, Abebe D, Urga K: A survey of traditional medicine in Shirka District, Arsi Zone, Ethiopia. Ethiop pharm j 200I, 19:30-47.

6. Govaerts R: How many species of seed plants are there? Taxon 200I, 50:1085-1090.

7. Schippmann U, Leaman DJ, Cunningham AB: Impact of Cultivation and Gathering of Medicinal Plants on Biodiversity: Global Trends and Issues. In (FAO) Biodiversity and the ecosystem approach in agriculture, forestry and fisheries. Satellite event on the occasion of the Ninth regular session of the commission on genetic resources for food and agriculture. Rome 12 - 13 October, 2002 Inter departmental working group on biological diversity for food and agriculture; Rome; 2002.

8. Pankhurst R: An historical examination of traditional Ethiopian medicine and surgery. Eth Med J 1965, 3(4): I57-I72.

9. Pankhurst R: An introduction to the medical history of Ethiopia Trenton, New Jersey: The Red Sea Press, INC; 1990.

10. Slikkerveer LJ: Plural medical systems in the Horn of Africa: The legacy of "Sheik" Hippocrates London and New York: Kegan-Paul International; 1990.

II. Abebe D, Ayehu A: Medicinal plants and enigmatic health practices of northern Ethiopia B. S. P. E.: Addis Ababa, Ethiopia; 1993.

12. Vecchiato NL: Traditional medicine. In The ecology of health and disease in Ethiopia Edited by: Kloos H, Zein A. Boulder: Sanfrancisco and Oxford Westview Press; 1993.

13. Iwu MM: Handbook of African medicinal plants Boca Raton: CRC Press; 1993.
14. Abbink J: Medicinal and ritual plants of the Ethiopian South West. An account of recent research. Indigenous knowledge and development monitor 1995, 3(2):6-8.

15. Pankhurst R: The status and Availability of oral and written knowledge on traditional health care in Ethiopia. In Proceedings of the National Workshop on Biodiversity Conservation and Sustainable Use of Medicinal Plants in Ethiopia. 28 April - 0I may, 1998 IBCR: Addis Ababa; 2001:92-106.

16. Fassil H: Beyond Plants, Professionals \& Parchments: The role of home-based medicinal plant use and traditional health knowledge in primary health care in Ethiopia. Ethnobotany Research \& Applications 2005, 3:037-049.

17. Martin G]: Ethnobotany. A Methods Manual WWF for Nature International, London, UK: Chapman and Hall; 1995.

18. The National Herbarium of Addis Ababa University: Flora of Ethiopia, Volume 3: Pittosporaceae to Araliaceae Addis Ababa; 1989.

19. The National Herbarium of Addis Ababa University: Flora of Ethiopia and Eritrea, Volume 2, Part 2: Canellaceae to Euphorbiaceae Addis Ababa; 1995.

20. The National Herbarium of Addis Ababa University: Flora of Ethiopia and Eritrea, Volume 2, Part 1: Magnoliaceae to Flacourttiaceae Addis Ababa; 2000.

21. The National Herbarium of Addis Ababa University: Flora of Ethiopia and Eritrea, Volume 6: Hydrocharitaceae to Arecaceae Addis Ababa; 1997.

22. Heinrich M, Ankli A, Frei B, Weimann C, Sticher O: Medicinal plants in Mexico: Healers' consensus and cultural importance. Social Science and Medicine 1998, 47:1863-1875.

23. Alexiades $M N$ : Selected Guidelines for Ethnobotanical Research: A Field Manual. In Advances in Economic Botany Volume 10. Bronx: The New York Botanical Garden; 1996.

24. Rekdal OB: Cross Cultural Healing in East African Ethnography. Medical Anthropology Quarterly 1999, I 3(4):458-482.

25. Bishaw B: Attitudes of modern and traditional medical practitioners toward cooperation. Ethiop Med J 1990, 28:63-72.

26. Tesfu CB, Mengistu B, Wolde Aregay G: Women Lead in Protecting Food Germplasm and Herbs for Health in Ethiopia Report submitted to EarthCare Africa, Nairobi, Kenya (unpublished); 1995.

27. Schulz V, Hänsel R, Tyler VE: Rational phytotherapy. A physician's guide to herbal medicine 4th edition. Berlin: Springer-Verlag; 2001. 
28. Tessema T, Giday M, Aklilu N: Stacking and information on the medicinal plants of Ethiopia. In National Biodiversity strategy and action plan project Medicinal plant Team, Addis Ababa: IBDA; 200 I.

29. Giday M, Ameni G: An Ethnobotanical survey on plants of veterinary importance in two Woreda of southern Tigray, Northern Ethiopia. Ethiopian J Sci 2003, 26(2): 123-136.

Publish with Bio Med Central and every scientist can read your work free of charge

"BioMed Central will be the most significant development for disseminating the results of biomedical research in our lifetime. " Sir Paul Nurse, Cancer Research UK

Your research papers will be:

- available free of charge to the entire biomedical community

- peer reviewed and published immediately upon acceptance

- cited in PubMed and archived on PubMed Central

- yours - you keep the copyright

Submit your manuscript here:

http://www.biomedcentral.com/info/publishing_adv.asp
Biomedcentral 